\title{
Assessing Context-Specific Factors to Increase Tree Survival for Scaling Ecosystem Restoration Efforts in East Africa
}

\author{
Christine Magaju 1,*(1), Leigh Ann Winowiecki ${ }^{1}\left(\mathbb{C}\right.$, Mary Crossland $^{2}$, Aymen Frija ${ }^{3}(\mathbb{D}$, \\ Hassen Ouerghemmi ${ }^{3}$, Niguse Hagazi ${ }^{4}$, Phosiso Sola ${ }^{1}{ }^{\mathbb{C}}$, Ibrahim Ochenje ${ }^{1}$, Esther Kiura ${ }^{1}$, \\ Anne Kuria ${ }^{1}$, Jonathan Muriuki ${ }^{1}$, Sammy Carsan ${ }^{1}$, Kiros Hadgu ${ }^{4}$, Enrico Bonaiuti ${ }^{5}$ (D) \\ and Fergus Sinclair 1,2 \\ 1 World Agroforestry (ICRAF), UN Avenue, P.O. Box 30677, Nairobi 00100, Kenya; \\ l.a.winowiecki@cgiar.org (L.A.W.); p.sola@cgiar.org (P.S.); ibraochenje@gmail.com (I.O.); \\ muthoni.kiura@gmail.com (E.K.); a.kuria@cgiar.org (A.K.); j.muriuki@cgiar.org (J.M.); \\ s.carsan@cgiar.org (S.C.); f.sinclair@cgiar.org (F.S.) \\ 2 School of Natural Sciences, Bangor University, Bangor, Gwynedd LL57 2DG, UK; afp43d@bangor.ac.uk \\ 3 International Center for Agricultural Research in the Dry Areas, ICARDA, Rue Hedi Karray, \\ CP 2049 Ariana, Tunisia; a.frija@cgiar.org (A.F.); ouerghemmihassen@gmail.com (H.O.) \\ 4 World Agroforestry (ICRAF), Gurd Shola, P.O. Box 5689 Addis Ababa, Ethiopia; n.hagazi@cgiar.org (N.H.); \\ k.hadgu@cgiar.org (K.H.) \\ 5 International Center for Agricultural Research in the Dry Areas, ICARDA, 6/106, Osiyo St, \\ Tashkent 100084, Uzbekistan; E.Bonaiuti@cgiar.org \\ * Correspondence: c.magaju@cgiar.org
}

Received: 30 October 2020; Accepted: 27 November 2020; Published: 4 December 2020

\begin{abstract}
Increasing tree cover in agricultural lands can contribute to achieving global and national restoration goals, more so in the drylands where trees play a key role in enhancing both ecosystem and livelihood resilience of the communities that depend on them. Despite this, drylands are characterized by low tree survival especially for tree species preferred by local communities. We conducted a study in arid and semi-arid areas of Kenya and Ethiopia with 1773 households to assess how different tree planting and management practices influence seedling survival. Using on-farm planned comparisons, farmers experimented and compared tree survival under different planting and management practices as well as under varying socioeconomic and biophysical contexts in the two countries. Seedling survival was monitored at least six months after planting. Results show that watering, manure application, seedling protection by fencing and planting in a small hole $(30 \mathrm{~cm}$ diameter and $45 \mathrm{~cm}$ depth) had a significant effect on tree seedling survival in Kenya, while in Ethiopia, mulching, watering and planting niche were significant to tree survival. Household socioeconomics and farms' biophysical characteristics such as farm size, education level of the household head, land tenure, age of the household head had significant effects on seedling survival in both Ethiopia and Kenya while presence of soil erosion on the farm had a significant effect in Kenya. Soil quality ranking was positively correlated with tree survival in Ethiopia, regardless of species assessed. Current findings have confirmed effects of context specific variables some involving intrahousehold socioeconomic status such education level of the household head, and farm size that influence survival.
\end{abstract}

Keywords: trees on farm; options by context; on-farm planned comparison; tree seedling survival

\section{Introduction}

Restoration and avoiding further degradation through tree (re)establishment can be a key pathway towards achieving the UN's Sustainable Development Goals if successful restoration efforts can reach 
larger numbers of farmers and hectares over the coming decade. In fact, several global initiatives and commitments have come up in recognition of the need to intensify restoration efforts. This includes the UN decade on ecosystem restoration whose goal is to prevent, halt and reverse degradation of ecosystems by acting as an accelerator for ongoing restoration efforts ${ }^{1}$; the Bonn Challenge whose goal is to restore 150 million hectares of degraded and deforested landscapes by 2020 and 350 million hectares by $2030^{2}$; and the African Forest Landscape Restoration Initiative (AFR100) in which countries have committed to restoring 100 million hectares of degraded land in Africa by $2030^{3}$. Ethiopia and Kenya have each committed to restore 15 and 5.1 million hectares, respectively, as a contribution to AFR100 and the Bonn challenge. In addition, Kenya, through its national strategy, aims at achieving and maintaining over $10 \%$ tree cover by 2022 [1].

Achieving the restoration goals outlined in international and national commitments will require promotion of context-specific land restoration options across diverse social, economic, and biophysical realities [2-4]. These options will also need to be scaled up and out across the scaling domains [5]. For the most part, farmers targeted by restoration efforts work in complex, heterogenous and dynamic systems and, as such, no one single restoration option can suit all [3,4,6,7]. Many factors, both socioeconomic and biophysical, can affect the suitability and performance of the restoration options at different scales [8]. These include household characteristics such as farm size, age of the household head as well as education level and labor availability, farming practices, land degradation status, the policy environment $[5,9]$ as well as farmer values and preferences $[5,6,10,11]$.

Therefore, to understand which options are suitable, we must be cognizant of the variation within and between farms, landscapes and communities for all the context variables that might be important [3]. We must also take into account the goals, values and preferences of the people living on the land $[6,10,11]$. It is also imperative to consider the impact of restoration options such as tree planting on gender dynamics within a household if we are to ensure women, men and the youth benefit from restoration [10,12-14]. This includes understanding the roles and responsibilities of men and women in managing natural resources, decision-making within restoration options for example, who decides what restoration options to take part in and where on the farm these options are implemented.

Tree (re)establishment on agricultural land through natural regeneration or direct planting is often considered a key approach to restoration in the drylands [15-17]. This is largely driven by the recognition of the vital role that trees play in enhancing ecosystem and livelihood resilience [18-20]. Trees, for example, provide goods and services such as food and fuel, enhancing soil health, enhancing biodiversity, opportunities for generating income and contributing to climate change mitigation and adaptation [21-23]. However, low survival rates of planted trees, especially species highly valued by farmers, is a major limitation in the drylands [19,20]. This is partly due to unreliable rainfall, high levels of land degradation resulting in low soil productivity, planting of ecologically unsuitable tree species, and poor tree seedling management practices $[18,19,24]$.

Understanding what determines tree seedling survival is fundamental to successful tree planting initiatives. For example, which trees species are suitable for which ecological context, which tree species farmers prefer, and what management practices increase tree survival in the different agroecological and socioeconomic conditions. In this paper, we evaluate how tree seedling planting and management practices influence tree survival across various agroecological conditions and the farmer circumstances in Ethiopia and Kenya, as well as the effect of socioeconomic and farm characteristics on tree survival.

\footnotetext{
https://www.decadeonrestoration.org/

https://www.bonnchallenge.org/

https://afr100.org/
} 


\section{Materials and Methods}

The study was conducted within the context of a donor-funded project, 'Restoration of degraded land for food security and poverty reduction in East Africa and the Sahel: taking success in land restoration to scale' ${ }^{4}$, (henceforth referred to as 'Restoration project'). The project's goal was to reduce food insecurity and improve livelihoods of poor people living in African drylands by restoring degraded land, and returning it to effective and sustainable tree, crop and livestock production, thereby increasing land profitability and landscape and livelihood resilience. To achieve this, the project employed a Research in Development (RinD) approach in which research activities are embedded within development activities [3]. Thus, the activities of the Restoration project were co-located with those of the Drylands Development Program ${ }^{5}$, (henceforth referred to as 'DryDev'), an international development initiative.

A key aspect of RinD that was implemented by the restoration project, is the use of planned comparisons, an approach where farmers compare and test promising options, and variations thereof, in their fields across a varying range of ecological and socioeconomic conditions [3-5,24,25]. Ref. [26] defines planned comparisons as the systematic and deliberate comparison of options where options refer to what is being done differently to address a particular challenge [25]. The approach involves engagement of local communities including farmers, researchers, government extension agents, and development actors in identifying current challenges facing farmers, selecting and prioritizing the initial set of promising options to be compared, and in monitoring the performance of the options being compared. Involvement of local communities has an impact on the outcome on whether the options succeed or fail and, in most cases, local communities are responsible for long-term management of these options $[27,28]$.

\subsection{Site Description}

The study was conducted across four woredas in Tigray and Oromia regions in Ethiopia and across six subcounties in Kitui, Machakos and Makueni counties in Kenya. Specifically, the study took place in Boset and Gursum woredas in the Oromia region of Ethiopia, Samre and Tsaeda Emba woredas in the Tigray region of Ethiopia. In Kenya, the study covered Kitui Rural and Mwingi East subcounties in Kitui, Mwala and Yatta subcounties in Machakos, and Mbooni East and Kibwezi East subcounties in Makueni counties in the Eastern drylands of Kenya (Figure 1).

All the sites in Ethiopia are classified as semi-arid with annual rainfall ranging from $400 \mathrm{~mm}$ to $800 \mathrm{~mm}$ which varies from year to year [29] and are located between $779 \mathrm{~m}$ and $1362 \mathrm{~m}$ above sea level. The sites are characterized by low vegetation cover, low soil fertility, high rates of soil erosion, and recurrent droughts [29,30]. The study area in Kenya is largely arid and semi-arid and is characterized by highly erratic and unreliable rainfall. Annual average rainfall varies across and within the three counties. For example, Machakos receives an average of $500 \mathrm{~mm}$ to $1250 \mathrm{~mm}$ per annum while Makueni receives $250-400 \mathrm{~mm}$ in the lower region and $800-900 \mathrm{~mm}$ in the higher regions. Annual average temperature also varies across the three counties. In Kitui, annual temperatures ranges from $14-32{ }^{\circ} \mathrm{C}$, in Machakos from $14-32{ }^{\circ} \mathrm{C}$ and in Makueni from $20.2-24{ }^{\circ} \mathrm{C}$ [31-33].

Agriculture is the dominant land use in all the sites and is characterized by low input subsistence farming. Main crops grown across the sites in Ethiopia include Eragrostis tef, Triticum, Zea mays and Sorghum bicolor, while Zea mays, Sorghum bicolor, Pennisetum glaucum, and pulses such as Phaseolus vulgaris and Vigna unguiculata are commonly grown across the sites in Kenya. The majority of households also own livestock.

4 http://www.worldagroforestry.org/project/restoration-degraded-land-food-security-and-poverty-reduction-east-africaand-sahel-taking

5 http://www.worldagroforestry.org/project/drylands-development-programe-drydev 


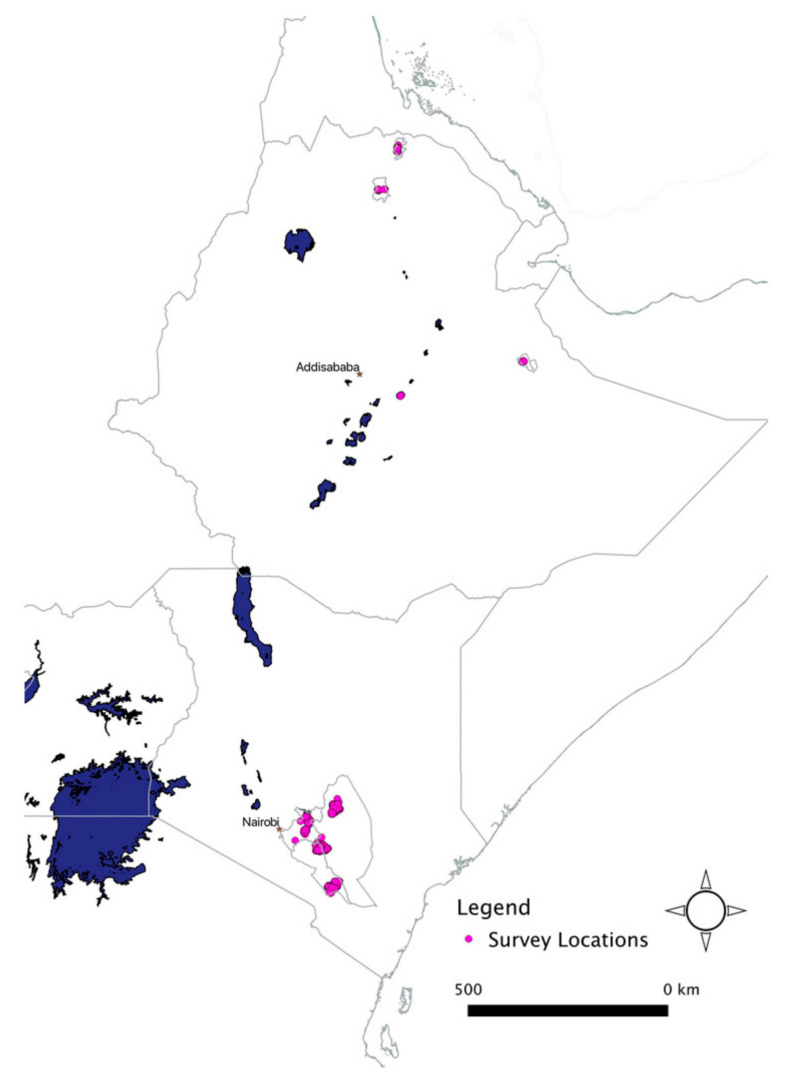

Figure 1. Map of the study locations in Ethiopia and Kenya.

\subsection{Tree Planting Planned Comparison}

The planned comparison on tree planting and management options was set up in response to a need by local communities in the study area to increase tree seedling survival. They identified tree planting and management as a learning priority during DryDev's community visioning and planning process [34]. Specifically, farmers identified low survival rates of planted trees as a key constraint to increasing tree cover and expressed interest in learning about planting and management methods that could increase establishment rates. Thus, the objective of the planned comparison on tree planting was to understand which planting and management practices can increase tree seedling survival rates for farmers across the study sites. More so, the practices that conferred the best chance of survival for the planted tree seedlings.

One thousand seven hundred and seventy-three households in both Kenya and Ethiopia volunteered to take part in the planned comparison during subsequent stakeholder and community engagement meetings. They compared the effect of different planting and management practices on seedling survival. Options compared included: tree species, planting hole sizes, planting with manure or without, physical protection of seedlings from livestock through spot fencing, and watering (Table 1). Water availability is a limiting factor for seedling survival in the study sites, thus the options compared were prioritized to increase the amount of water available to the seedlings after establishment. For example, digging a bigger planting hole to increase water capture thus increasing the rate of infiltration. This ensures that seedlings have sufficient water for initial growth and establishment [35]. Furthermore, browsing by livestock is one of the leading causes of seedling mortality. 
Table 1. Options and contexts compared in the tree planting on-farm planned comparisons.

\begin{tabular}{|c|c|}
\hline \multicolumn{2}{|l|}{ Options Compared } \\
\hline Tree species & Categorical variable \\
\hline Manure & Categorical variable with two levels, yes or no \\
\hline Mulching & $\begin{array}{l}\text { Categorical variable with two levels, yes or no } \\
\text { (Mulch: a mix of grass, maize stalk and leaf litter is spread around the base of the } \\
\text { seedling) }\end{array}$ \\
\hline Hole size (diameter and depth) & $\begin{array}{l}\text { Categorical variable with three levels (i) small hole }(30 \mathrm{~cm} \text { by } 45 \mathrm{~cm}) \text {; (ii) big hole } \\
(60 \mathrm{~cm} \text { by } 45 \mathrm{~cm} \text { ); (iii) farmer usual hole size (diameter is not equal to } 30 \mathrm{~cm} \text { or } 60 \mathrm{~cm} \text { ) }\end{array}$ \\
\hline Watering & Categorical variable with two levels, yes or no \\
\hline Watering frequency (Kenya) & $\begin{array}{l}\text { Categorical variable with five levels (i) daily; (ii) every other day; (iii) weekly; (iv) } \\
\text { bi-weekly; (v) monthly }\end{array}$ \\
\hline Watering regime (Ethiopia) & $\begin{array}{l}\text { Categorical variable with four levels (i) five litres every five days; (ii) five litres every } \\
\text { ten days; (iii) three litres every five days; (iv) three litres every ten days }\end{array}$ \\
\hline Fencing & $\begin{array}{l}\text { Categorical variable with two levels, yes or no } \\
\text { (physical protection of seedlings from livestock) }\end{array}$ \\
\hline Pruning & Categorical variable with two levels, yes or no \\
\hline Shading & Categorical variable with two levels, yes or no \\
\hline Planting niche & $\begin{array}{l}\text { Categorical variable with six levels, (i) external boundary; (ii) internal boundary; (iii) } \\
\text { scattered in cropland; (iv) woodlot; (v) home compound; (vi) along terraces. } \\
\text { (Planting niche: where on the farm the seedlings are planted) }\end{array}$ \\
\hline \multicolumn{2}{|l|}{ Contexts Compared } \\
\hline Age of household head & Continuous variable \\
\hline Gender of household head & Categorical variable with two levels: (i) male; (ii) female \\
\hline Education level of the household head & $\begin{array}{l}\text { Categorical variable with four levels (i) no formal schooling; (ii) primary; (iii) } \\
\text { secondary; (iv) tertiary (college/university/vocational) }\end{array}$ \\
\hline Farm size (ha) & Continuous variable \\
\hline Land tenure & $\begin{array}{l}\text { Categorical variable with six levels: (i) private through purchase; (ii) private through } \\
\text { customary inheritance; (iii) communal land; (iv) government; (v) settlement scheme; } \\
\text { (vi) leasing }\end{array}$ \\
\hline Erosion status & $\begin{array}{l}\text { Categorical variable with two levels, yes or no. (Erosion status: Farmer experience } \\
\text { with problems of soil erosion on the farm) }\end{array}$ \\
\hline Soil quality ranking & $\begin{array}{l}\text { Categorical variable with three levels (i) high (Good yields can be obtained without } \\
\text { adding either chemical fertilizer or farmyard manure/compost); (ii) medium (Yields } \\
\text { can be maximized with chemical fertilizer or farmyard manure/compost but fair } \\
\text { yields can be obtained without); (iii) low (very little can grow without significant } \\
\text { addition of chemical fertilizer or farmyard manure/compost). (Soil quality ranking: } \\
\text { Farmer description of soil quality on the farm) }\end{array}$ \\
\hline
\end{tabular}

Farmers were trained on the various management options and on setting up the on-farm planned comparisons during several opportunities, during farmer workshops. This included practical training on how to set up the options being compared. Farmers had the choice of which option to implement and compare on their farms on condition of likeness. The number of options tested was subject to farmer interest and available resources for example if the farmer had access to manure or not. Farmers also had the choice of where on their farm to plant the seedlings (i.e., planting niche). Seedlings could be planted across all preferred niches provided variation in the farm characteristics was considered to ensure seedlings of a similar species were as homogenous as possible.

Implementing partners across the study sites distributed seedlings to farmers subsequent to training events. Tree seedlings were sourced from different nurseries across the study sites due to the large number required and the nature of the nursery enterprises in the study area. Seedlings were delivered potted in $10 \mathrm{~cm}$ by $15 \mathrm{~cm}$ potting bags and were on average, of good quality with variation depending on the nursery. The size of the seedlings varied depending on the nursery from which they were sourced. Farmers planted the seedlings within a week of receiving them. 
In Kenya and Ethiopia, tree species selection was conducted through a consultative stakeholder engagement process. Twenty tree species were monitored in Ethiopia: Acacia saligna, Azadirachta indica, Carica papaya, Casimiroa edulis, Citrus sinensis, Coffea arabica, Cordia africana, Faidherbia albida, Grevillea robusta, Jacaranda mimosifolia, Malus domestica, Mangifera indica, Melia volkensii, Moringa oleifera, Olea africana, Persea americana, Psidium guajava, Rhamnus prinodes and Vachellia seyal. In Kenya, seven tree species were monitored: Calliandra calothyrsus, Melia volkensii, Senna siamea, Mangifera indica, Carica papaya, Azadirachta indica and Moringa oleifera. Farmers planted at least seven seedlings of each the selected species, applying the various management practices. Some species were planted exclusively in one woreda or county. For example, Jacaranda mimosifolia was only planted in Gursum Woreda while Carica papaya and Melia volkensii were exclusively planted in Boset Woreda, and in Kenya, Calliandra calothyrsus was only planted in Mwala, Machakos County.

\subsection{Data Collection and Analysis}

Data on tree seedling survival was collected from all households that received and planted tree seedlings through the project. Only tree seedlings planted as part of the on-farm planned comparisons were assessed. We assessed seedling survival under different planting and management practices at least six months after the seedlings were planted as it is widely accepted that the first six months after planting are most critical for survival as seedlings acclimatize and establish. This was done using a structured survey questionnaire administered through the Open Data Kit (ODK) ${ }^{6}$ installed on mobile phones). Seedling survival was recorded as a categorical variable with two levels: yes or no represented by dummy variables 1 and 0 . To understand men's and women's involvement in tree planting and management thereof, we collected information on the roles and responsibilities of men and women in decision-making within tree planting interventions.

We used a household survey to collect data on all farmers involved in the project. The survey included collection of basic socioeconomic and biophysical characteristics of the household and farm. Household demographic information collected included gender and age of household head, education level of the household head and household size. Farm characteristics such as farm size and ownership; soil erosion and control measures, trees on farm including the count, management and utility derived from the trees; crop and livestock production, climate change, including farmers' understanding, experience and response to climate change; and food security were also collected. We also conducted a tree inventory of the existing tree species within the household including data on species diversity within farms.

Statistical analysis on survival of planted trees under different planting and management options was conducted using the $\mathrm{R}$ software environment [36] including logistic regression to ascertain the probability of tree seedling survival under different management practices, and household socioeconomic and farm characteristics. Variation in the type and magnitude of the effect across the agroecological conditions represented in the study sites was also examined using a mixed-effect linear model. Since seedling survival varied highly across the tree species in Kenya, the effect of tree species was included as a constant in the model for Kenya. As not all practices were employed across the two countries, only those that were universally employed were compared across both countries in the results. For example, manure and variation in planting hole size was only assessed in study sites in Kenya while watering regime, disease, weed and pest control were only assessed in study sites in Ethiopia. Table 2 shows the number of observations in each option.

6 https://opendatakit.org/ 
Table 2. Number of tree seedlings under each option in Kenya and Ethiopia. Where available, a common name for each species is added in the brackets.

\begin{tabular}{lccccccc}
\hline Country & Tree Species & Fencing & Manure & Mulch & Watering & Shade & Fertilizer \\
\hline Ethiopia & Acacia saligna & 14 & - & 4 & 12 & - & - \\
& Azadiracta indica (Neem) & 75 & - & 62 & 91 & - & - \\
& Carica papaya (Papaya) & 1 & - & & & - & - \\
& Casimiroa edulis (White sapote) & 5 & - & 13 & 19 & - & - \\
& Citrus sinensis (Sweet orange) & 172 & - & 102 & 155 & - & - \\
& Coffea arabica (Arabica coffee) & 36 & - & 35 & 55 & - & - \\
& Cordia africana & 1 & - & & 1 & - & - \\
& Faidherbia albida (Apple- ring acacia) & 114 & - & 128 & 212 & - & - \\
& Grevillea robusta (Silver oak) & 450 & - & 222 & 346 & - & - \\
& Jacaranda mimosifolia & 6 & - & 12 & 11 & - & - \\
& Malus domestica (Apple) & 1 & - & & 1 & - & - \\
& Mangifera indica (Mango) & 571 & - & 375 & 541 & - & - \\
& Moringa oleifera (Moringa) & 154 & - & 89 & 129 & - & - \\
Olea africana & 2 & - & & & - & - \\
& Persea americana (Avocado) & 105 & - & 42 & 97 & - & - \\
Psidium guajava (Guava) & 118 & - & 100 & 124 & - & - \\
Rhamnus prinoides & 111 & - & 119 & 191 & - & - \\
& Vachellia seyal (Shittah tree) & 2 & - & 1 & 2 & - & - \\
Kzadirachta indica (Neem) & 899 & 1533 & 660 & 2436 & 82 & 8 \\
Calliandra calothyrsus & 50 & 61 & 29 & 165 & 43 & 2 \\
& Carica papaya (Pawpaw) & 276 & 239 & 162 & 307 & 84 & - \\
Mangifera indica (Mango) & 2157 & 4339 & 1658 & 6432 & 618 & 22 \\
Melia volkensii (Melia) & 1113 & 1812 & 849 & 3221 & 335 & - \\
& Moringa oleifera (Moringa) & 167 & 489 & 113 & 883 & 41 & 9 \\
& Senna siamea (Siamese senna) & 662 & 1005 & 346 & 1808 & 59 & 25 \\
\hline
\end{tabular}

\section{Results}

Data were collected from 173 households across the sites in Ethiopia in 2017 [37] and 1600 households in Kenya in 2018 [38]. Of these, 71\% and 76\% surveyed households in Kenya and Ethiopia were male-headed, respectively. Despite this, it was mostly women (i.e., their spouse) who registered to join the project and attended the training events. Median farm size was 2.02 Ha in Kenya and ranged from $0.05 \mathrm{Ha}$ to $3.33 \mathrm{Ha}$ while in Ethiopia, median farm size was $1 \mathrm{Ha}$ and ranged from $0.1 \mathrm{Ha}$ to $8 \mathrm{Ha}$. Household head age ranged from 18 years to 80 years in Ethiopia with a median of 40.5 years while in Kenya the age ranged from 23 years to 97 years with a median of 49 years.

\subsection{Overview of Tree Seedling Survival}

In Ethiopia, 4224 trees were monitored in 2017 and 17,520 trees were monitored in Kenya in 2018.

Overall, average seedling survival in the two countries varied across the species planted and agroecological conditions represented in the study sites. In Kenya, Kitui County had the highest average seedling survival at $53.4 \%$ while Machakos and Makueni counties had an average survival of $32.2 \%$ and $43.3 \%$, respectively. The variation in average survival was also observed within each county. Highest variation was recorded in Makueni County with Mbooni East recording 66.7\% survival compared to Kibwezi East which had survival rate of 33.8\%. Comparatively, average seedling survival was high across all the woredas in Ethiopia. Tsaeda Emba and Boset had the highest average tree survival at $99 \%$ and $93 \%$ respectively while Gursum and Samre recorded $84 \%$ and $81 \%$ survival of all the trees planted respectively. Variation in average seedling survival was however observed within each woreda with highest variation recorded in Samre where Bara watershed recorded 95.8\% seedling survival compared to Atami watershed which recorded $72.1 \%$ survival. We also found that different tree species performed better in some areas compared to others despite the broad similarities in agroecological conditions in Kenya (Figure 2) and Ethiopia (Table 3). 




Figure 2. Boxplot of percentage tree seedling survival across the sites in Kenya ( $\mathrm{n}=7375$ seedlings). The black horizontal line is the average percentage survival for each species and the gray shaded area shows the distribution of the data.

Table 3. Percentage seedling survival per species in each site in Ethiopia (number of trees monitored in each species is added in brackets).

\begin{tabular}{ccccc}
\hline Tree Species & Boset & Gursum & Samre & Tsaeda Emba \\
\hline Acacia saligna & $100(1)$ & $100(5)$ & & $100(8)$ \\
Azadiracta indica & $66.7(125)$ & $85.5(69)$ & & \\
Carica papaya & $100(1)$ & & & $100(19)$ \\
Casimiroa edulis & & & $93.8(160)$ & \\
Citrus sinensis & & & $100(59)$ \\
Coffea arabica & & & $100(1)$ \\
Cordia africana & $100(1)$ & & & $100(215)$ \\
Faidherbia albida & $93.6(125)$ & $71.3(94)$ & $87.7(285)$ & \\
Grevillea robusta & & $91.7(12)$ & & \\
Jacaranda mimosifolia & $100(2)$ & $100(1)$ & & $99.5(204)$ \\
Malus domestica & $94.1(169)$ & $94.7(95)$ & $72.5(280)$ & \\
Mangifera indica & $50(2)$ & & & $100(1)$ \\
Melia volkensii & & & & \\
Moringa oleifera & $100(8)$ & & & $100(60)$ \\
Olea africana & $97.8(45)$ & $76.7(103)$ & & $100(2)$ \\
Persea americana & & $91.5(94)$ & & \\
Psidium guajava & & & & \\
Rhamnus prinodes & & & & \\
Vachellia seyal & & &
\end{tabular}




\subsection{Effect of Tree Planting and Management Practices on Seedling Survival}

Results show that despite influencing average survival, application of manure, watering regime, planting in a small hole relative to a big hole, and planting along the external boundary had a positive effect on seedling survival in Kenya (Table 4) while in Ethiopia, mulching, watering and physical protection were significant (Table 5). The type of effect (whether positive or negative) and magnitude of effect varied across the practices the sites where they were applied.

Overall, addition of manure increased seedling survival in Kenya by $12 \%$ with variation in the magnitude of effect across and within the counties. For example, we found that seedling survival in Kitui County increased by $8 \%$ with addition of manure while in Machakos and Makueni survival increased by $6 \%$ and $21 \%$ respectively. At subcounty level, Mbooni East in Makueni County had the greatest increase in seedling survival with addition of manure at $18.7 \%$. There was no variation in the magnitude of the effect of manure at the species level although results of the model show that application of manure increased survival of all species by $10 \%$. Addition of mulch had a positive effect on seedling survival and was significant in both Kenya and Ethiopia increasing survival by $5.8 \%$ and $5 \%$ respectively. Nevertheless, variation in the magnitude of the effect was observed across and within counties and woredas.

Watering the seedlings had a positive effect on tree survival and was significant in the two countries. In Kenya, survival increased by $35 \%$ when seedlings were watered with variation within and across the counties. Watering had the greatest effect on survival in Kitui (51\% increase) and Makueni Counties (43\% increase), which are considerably drier than Machakos County which recorded 7.5\% increase in survival with watering. In Ethiopia, survival increased by $63 \%$ when the seedlings were watered. Farmers also compared four watering regimes in Ethiopia. They compared watering with five liters of water every five days, five liters every ten days, three liters every five days, and three liters every ten days. Our results show that the watering regime employed was not significant as long the seedlings were watered.

Planting in a small hole relative to a big hole had a negative effect on seedling survival in Kenya with variation across the counties. The greatest variation was observed in Machakos County where survival decreased by $21 \%$ when seedlings were planted in farmer hole size relative to a big hole. On the other hand, planting seedlings in a small hole relative to a big hole increased seedling survival by $12 \%$ in Makueni County and decreased survival by $2 \%$ and $8 \%$ in Machakos and Kitui Counties respectively. Variation in the effect of the size of planting hole was also observed across the tree species planted and was significant for Calliandra calothyrsus, Mangifera indica and Melia volkensii. For example, Mangifera indica had a $41.5 \%$ probability of survival when planted in a small hole compared to $45.6 \%$ when planted in a big hole and 39.3\% when planted in normal-sized hole.

Physical protection of seedlings (fencing) had a significant effect on seedling survival in Kenya while in Ethiopia physical seedling protection was not significant. Overall, fencing increased seedling survival by $7.8 \%$ and 5\% in Kenya and Ethiopia respectively. Variation in the type and magnitude of effect was observed across the counties and Woredas. For example, fencing increased survival by $9 \%$ and $15 \%$ in Machakos and Makeuni counties respectively and it decreased survival in Kitui County by $5 \%$. On the other hand, survival increased by $8.5 \%$ in Boset, $5.3 \%$ in Gursum, $23.9 \%$ in Samre and by $0.4 \%$ in Tsaeda Emba when seedlings were fenced.

Finally, in Kenya, seedlings had a higher probability of survival when planted in woodlots and along the internal boundary and a lower probability of survival when planted along external boundaries, home compound and along terraces. In Ethiopia, seedlings had a higher probability of survival when planted along external boundaries and a lower probability of survival when planted scattered in cropland. All seedlings planted along terraces recorded 100\% survival and, as such, were excluded from the regression model. 
Table 4. Results of a logistic model on the probability of seedling survival under different planting and

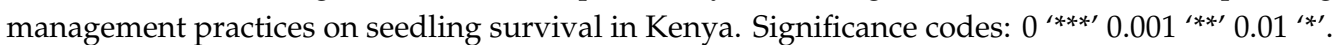

\begin{tabular}{|c|c|c|c|c|c|}
\hline Management Practice & $\mathbf{n}$ & Coefficient & Standard Error & $\operatorname{Pr}(>|z|)$ & Odds Ratio \\
\hline Manure application & 17,496 & & & & \\
\hline No & 17,470 & -0.495 & 0.226 & $0.029^{*}$ & \\
\hline Yes & & 0.466 & 0.033 & $<2 \times 10^{-16 * * *}$ & 1.641 \\
\hline Mulch application & & & & & \\
\hline No & 17,496 & 0.266 & 0.235 & 0.259 & \\
\hline Yes & & 0.233 & 0.041 & $1.34 \times 10^{-8 * * *}$ & 1.263 \\
\hline Watering & & & & & \\
\hline No & 17,496 & -1.918 & 0.220 & $<2 \times 10^{-16 * * *}$ & \\
\hline Yes & & 1.838 & 0.069 & $<2 \times 10^{-16 * * *}$ & 6.284 \\
\hline Watering frequency & & & & & \\
\hline Daily & 15,231 & 0.249 & 0.239 & 0.296 & 1.283 \\
\hline Every other day & & -0.063 & 0.069 & 0.363 & 0.939 \\
\hline Weekly & & 0.492 & 0.062 & $1.71 \times 10^{-15 * * *}$ & 0.611 \\
\hline Bi-weekly & & -0.299 & 0.071 & $2.68 \times 10^{-5 * * *}$ & 0.741 \\
\hline Monthly & & -0.416 & 0.143 & $0.004 * *$ & 0.66 \\
\hline Planting hole & 17.496 & & & & \\
\hline Big hole & $1 /, 496$ & -0.173 & 0.228 & 0.448 & 0.841 \\
\hline Small hole & & -0.103 & 0.036 & $0.004^{* *}$ & 0.902 \\
\hline Farmer normal hole size & & -0.046 & 0.071 & 0.52 & 0.955 \\
\hline Physical protection(fencing) & & & & & \\
\hline No & 17,496 & -0.380 & 0.235 & 0.106 & \\
\hline Yes & & 0.405 & 0.037 & $<2 \times 10^{-16 * * *}$ & 1.5 \\
\hline Planting Niche & 17,496 & & & & \\
\hline Along terraces & & -0.222 & 0.211 & 0.294 & \\
\hline External boundary & & -0.271 & 0.076 & $0.000 * * *$ & 0.762 \\
\hline Home compound & & -0.120 & 0.051 & 0.019 * & 0.886 \\
\hline Internal boundary & & -0.001 & 0.059 & 0.987 & 1.004 \\
\hline Scattered in cropland & & -0.114 & 0.050 & 0.023 * & 0.892 \\
\hline Woodlot & & 0.087 & 0.129 & 0.502 & 1.094 \\
\hline
\end{tabular}

Table 5. Results of a logistic model on the probability of seedling survival under different planting and

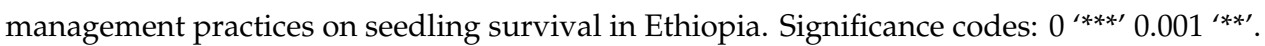

\begin{tabular}{|c|c|c|c|c|c|}
\hline Management Practice & $\mathbf{n}$ & Coefficient & Standard Error & $\operatorname{Pr}(>|z|)$ & Odds Ratio \\
\hline Mulch application & \multirow{3}{*}{2652} & & & & \\
\hline No & & 2.414 & 0.812 & 0.295 & \\
\hline Yes & & 1.008 & 0.14 & $6.18 \times 10^{-13 * * *}$ & 2.739 \\
\hline Watering & \multirow{3}{*}{2680} & & & & \\
\hline No & & -0.588 & 1.213 & 0.628 & \\
\hline Yes & & 5.021 & 0.366 & $<2 \times 10^{-16 * * *}$ & 151.608 \\
\hline Watering regime & \multirow{6}{*}{2070} & & & & \\
\hline Five liters every five days & & 3.447 & 1.028 & $0.001 * * *$ & \\
\hline Five liters every ten days & & -0.004 & 0.277 & 0.990 & 0.996 \\
\hline Three liters every five days & & -0.210 & 0.219 & 0.339 & 0.811 \\
\hline Three liters every ten days & & -0.121 & 0.274 & 0.659 & 0.886 \\
\hline Physical protection (fencing) & & & & & \\
\hline No & \multirow{2}{*}{2854} & 2.202 & 0.842 & $0.009^{* *}$ & \\
\hline Yes & & 0.831 & 0.175 & $2 \times 10^{-6 * * *}$ & 2.296 \\
\hline Planting Niche & \multirow{6}{*}{2695} & & & & \\
\hline External boundary & & 3.065 & 0.844 & $0.000 * * *$ & 21.432 \\
\hline Home compound & & 0.591 & 0.391 & 0.131 & 1.806 \\
\hline Internal boundary & & -0.538 & 0.359 & 0.134 & 1.713 \\
\hline Scattered in cropland & & -0.623 & 0.422 & 0.140 & 1.864 \\
\hline Woodlot & & -0.604 & 0.401 & 0.132 & 1.829 \\
\hline
\end{tabular}




\subsection{Options that Conferred the Best Chance of Survival for Planted Seedlings}

To assess the planting and management options that conferred the best chance of survival, we calculated the survival rate of tree species planted using a combination of the options tested (Table 6).

Table 6. Description of options derived from a combination of those tested in Kenya.

\begin{tabular}{|c|c|c|c|c|c|}
\hline Options & $\begin{array}{l}\text { Planting } \\
\text { Hole }\end{array}$ & Manure Quantity (kg) & Mulching & Watering & Observations \\
\hline Option 1 & Small* & 2 & No & No & 32 \\
\hline Option 2 & Small $^{*}$ & 2 & No & Yes & 630 \\
\hline Option 3 & Small* & 2 & Yes & No & 26 \\
\hline Option 4 & Small $^{*}$ & 2 & Yes & Yes & 298 \\
\hline Option 5 & Small* & 0 & Yes & No & 34 \\
\hline Option 6 & Small* & 0 & Yes & Yes & 516 \\
\hline Option 7 & $\mathrm{Big}^{* *}$ & 4 & No & No & 19 \\
\hline Option 8 & Big $^{* *}$ & 4 & No & Yes & 170 \\
\hline Option 9 & $\mathrm{Big}^{* *}$ & 4 & Yes & No & 7 \\
\hline Option 10 & $\mathrm{Big}^{* *}$ & 4 & Yes & Yes & 123 \\
\hline Option 11 & Big** $^{* *}$ & 0 & Yes & No & 20 \\
\hline \multirow{3}{*}{$\begin{array}{c}\text { Option } 12 \\
\text { Option } 0 \text { (Farmer's } \\
\text { practice) }\end{array}$} & $\mathrm{Big}^{* *}$ & 0 & Yes & Yes & 554 \\
\hline & Other ${ }^{* * *}$ & Other & No/Yes & No/Yes & 15,088 \\
\hline & Total & & & & 17,517 \\
\hline
\end{tabular}

Small $^{*}=30 \mathrm{~cm}$ diameter $\times 45 \mathrm{~cm}$ depth; Big ${ }^{* *}=60 \mathrm{~cm}$ diameter $\times 45 \mathrm{~cm}$ depth; Other ${ }^{* * *}=$ Common hole sizes.

In Kenya, seedlings planted in a big hole with $4 \mathrm{~kg}$ of manure and mulch had the highest survival at $47 \%$ while those planted in a small hole with $2 \mathrm{~kg}$ of manure and mulch had a survival of $36.1 \%$. Variation in percentage survival was observed across the species planted (Figure 3). For example, Azadirachta indica recorded higher survival when planted in a small hole with addition of mulch and two kilograms of manure while Moringa oleifera recorded higher survival when planted in a big hole with watering and addition of mulch. In Ethiopia, almost all combinations of the options conferred at least $90 \%$ chance of survival for the planted seedlings. However, seedlings that were not watered but were applied mulch and controlled for weed recorded the least survival at $44 \%$. This is consistent with the results of the statistical analysis where watering and watering regime were found to have a positive effect on survival of seedlings in Ethiopia.

\subsection{Effect of the Household Socioeconomic Characteristics on Tree Survival}

We assessed, using the household survey data, the effect of age and education level of the household head, land tenure, soil quality ranking (farmers ranked the quality of soil on their farm as either low, medium or high) and long-term experience with farms' soil erosion problems on seedling survival. In Kenya, our results showed that that there was a significant relationship between age and education level of the household head and seedling survival as well as between farm size, the type of land tenure and whether the farmer experienced soil erosion on their farm (Table 7). Variation was observed across the sites, for instance, in Mwingi Central, seedlings had a 59.3\% probability of survival when farmers described their soil quality as high compared to $47 \%$ when soil quality was ranked as low. In Kitui Rural however, seedlings had a higher probability of survival when farmers ranked their soil quality as low suggesting that the low soil quality rating was overcome by the management strategy. 


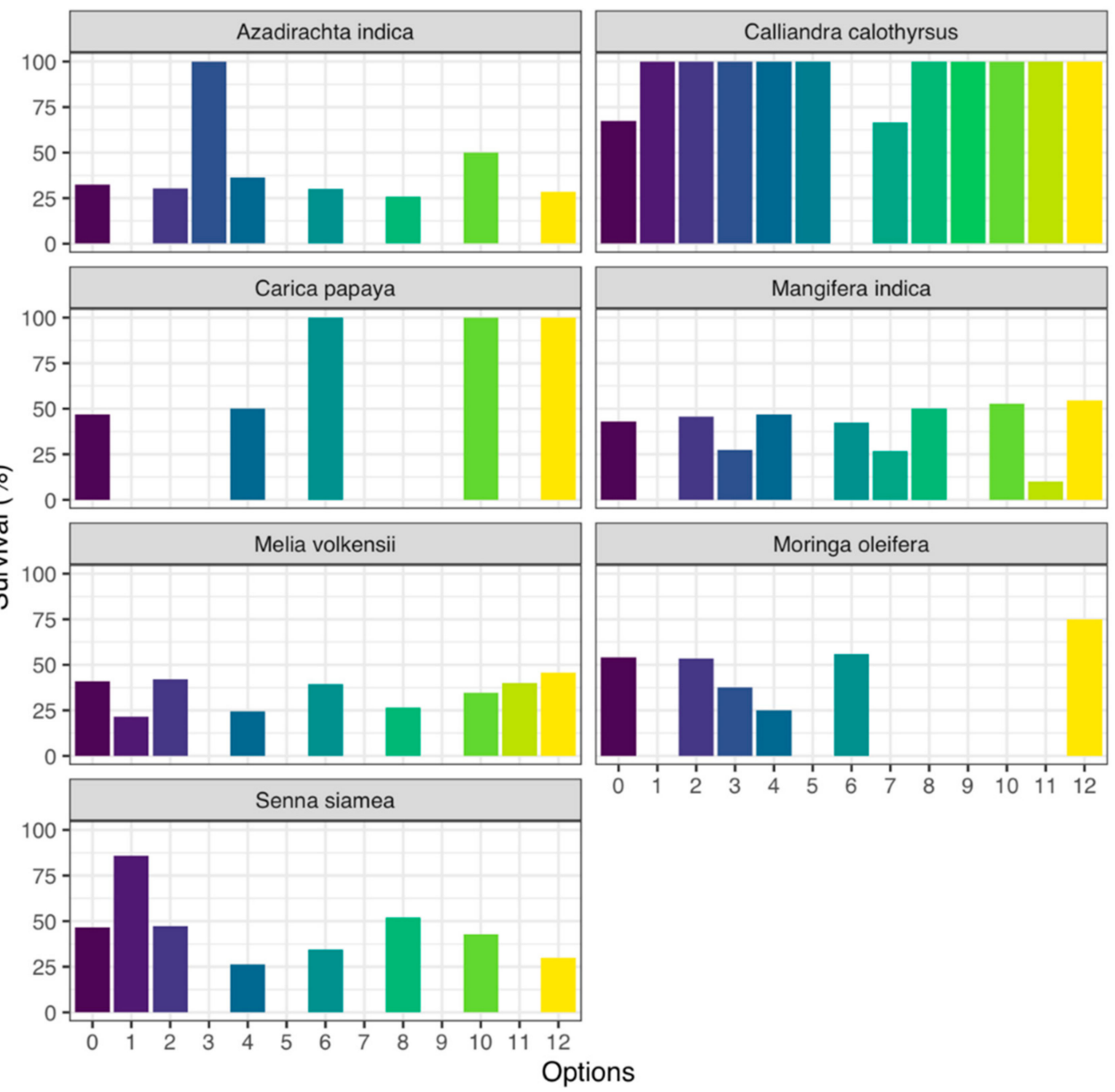

Figure 3. Performance of tree species against different combination of options that were tested in Kenya. Combinations presented here are described in Table 6.

Table 7. Results of the chi square test for a relationship between seedling survival and socioeconomic characteristics of a household and biophysical characteristics of the farm in Kenya. Significance levels: $1 \%^{* * * * \prime} 5 \%^{* * * \prime}$.

\begin{tabular}{|c|c|c|c|c|c|c|}
\hline Variables & $\begin{array}{c}\text { Seedling Survival } \\
(\text { yes }=1)\end{array}$ & $\mathbf{n}$ & $\begin{array}{l}\text { Chi Square } \\
\text { Value }\end{array}$ & $p$ Value & Cramer's V & Relationship \\
\hline Farm size & & 17,517 & $235.34^{* * *}$ & 0.000 & 0.12 & weak \\
\hline$\leq 2 \mathrm{Ha}$ & $3145(36 \%)$ & & & & & \\
\hline$>2 \mathrm{Ha}$ & $4239(47 \%)$ & & & & & \\
\hline Age category & & 17,517 & $50.95^{* * *}$ & 0.000 & 0.05 & Very weak \\
\hline$<35$ years & $518(40 \%)$ & & & & & \\
\hline $36-64$ years & $5833(44 \%)$ & & & & & \\
\hline$>65$ years & 1033 (37\%) & & & & & \\
\hline Education level & & 15,723 & $59.84^{* * *}$ & 0.000 & 0.06 & Very weak \\
\hline $\begin{array}{l}\text { No formal } \\
\text { education }\end{array}$ & $580(40 \%)$ & & & & & \\
\hline Primary education & $4117(44 \%)$ & & & & & \\
\hline $\begin{array}{l}\text { Secondary } \\
\text { education }\end{array}$ & $1484(38 \%)$ & & & & & \\
\hline Tertiary education & $437(49 \%)$ & & & & & \\
\hline Land tenure & & 16,009 & $94.83^{* * *}$ & 0.000 & 0.08 & Very weak \\
\hline Title deed/ & $4841(43 \%)$ & & & & & \\
\hline Allotment/leasehold & $1345(35 \%)$ & & & & & \\
\hline Others & $501(48 \%)$ & & & & & \\
\hline
\end{tabular}


Table 7. Cont.

\begin{tabular}{ccccccc}
\hline Variables & $\begin{array}{c}\text { Seedling Survival } \\
\text { (yes = 1) }\end{array}$ & $\mathbf{n}$ & $\begin{array}{c}\text { Chi Square } \\
\text { Value }\end{array}$ & $p$ Value & Cramer's V & Relationship \\
\hline Soil quality & $1166(44 \%)$ & 16,740 & $8.55^{* *}$ & 0.014 & 0.02 & Very weak \\
High & $1590(42 \%)$ & & & & & \\
Low & $4262(41 \%)$ & & & & & \\
Medium & $2372(40 \%)$ & 16,740 & $10.89 * * *$ & 0.001 & & \\
Erosion & $4646(43 \%)$ & & & & & \\
No & & & & & \\
Yes & & &
\end{tabular}

In Ethiopia, farm size and soil quality ranking had a significant relationship with seedling variation survival (Table 8). As soil quality ranking increased so did the likelihood of tree seedling survival (soil quality was ranked by the farmer as either low, medium or high).

Table 8. Results of the chi square test for a relationship between seedling survival and socioeconomic characteristics of a household and biophysical characteristics of the farm in Ethiopia. Significance

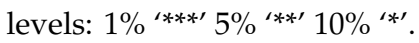

\begin{tabular}{|c|c|c|c|c|c|c|}
\hline Variables & $\begin{array}{c}\text { Seedling Survival } \\
(\text { yes }=1)\end{array}$ & $\mathbf{n}$ & $\begin{array}{l}\text { Chi Square } \\
\text { Value }\end{array}$ & $p$ Value & Cramer's V & Relationship \\
\hline Farm size & & 2854 & $22.72 * * *$ & 0.000 & 0.09 & Very weak \\
\hline$<=2 \mathrm{Ha}$ & $980(86 \%)$ & & & & & \\
\hline$>2 \mathrm{Ha}$ & $1562(91 \%)$ & & & & & \\
\hline Age category & & 2854 & $5.77^{*}$ & 0.056 & 0.05 & Very weak \\
\hline$<35$ years & $955(88 \%)$ & & & & & \\
\hline $36-64$ years & $1234(89 \%)$ & & & & & \\
\hline$>65$ years & $303(93 \%)$ & & & & & \\
\hline Education level & & 2710 & $9.58 * *$ & 0.022 & 0.06 & Very weak \\
\hline $\begin{array}{l}\text { No formal } \\
\text { education }\end{array}$ & $1079(87 \%)$ & & & & & \\
\hline Primary education & $1152(91 \%)$ & & & & & \\
\hline $\begin{array}{l}\text { Secondary } \\
\text { education }\end{array}$ & $176(86 \%)$ & & & & & \\
\hline Tertiary education & $7(78 \%)$ & & & & & \\
\hline Soil quality & & 2710 & $68.72 * * *$ & 0.000 & 0.16 & weak \\
\hline High & $17(44 \%)$ & & & & & \\
\hline Low & $516(42 \%)$ & & & & & \\
\hline Medium & $1986(41 \%)$ & & & & & \\
\hline
\end{tabular}

Variation in the effect of socioeconomic and biophysical variables was observed across the woredas. For example, increasing farm size decreased tree seedling survival in all woredas except Gursum which had increased tree survival with increased farm size.

\subsection{Gendered Management and Use of Trees}

In Kenya, analysis around intrahousehold decision-making over participation in the comparisons and division of labor in the management of trees was also conducted. The decision to get involved in the tree planting planned comparison was made by $94 \%$ of women respondents in female-headed households, $70 \%$ of women respondents in male-headed households and 70\% of men respondents in female-headed and male-headed households respectively. A similar trend was observed in who was involved in deciding which tree species to plant and where on the farm to plant the trees.

We also wanted to understand the division of labor when managing the planted trees as, traditionally, men and women tend to have differing roles as well as areas of influence when it comes to tree planting $[39,40]$. Our results show that women-only labor was commonly used for adding mulch (44\%), watering ( $42 \%)$, and adding manure (40\%) compared to men-only labor, which was used for planting trees, fencing and pruning (Table 9). 
Table 9. Gender of those involved in various management activities associated with tree planting.

\begin{tabular}{ccccc}
\hline & N * & $\begin{array}{c}\text { Male Labor } \\
\text { Only (\%) }\end{array}$ & $\begin{array}{c}\text { Male and Female } \\
\text { Labor (\%) }\end{array}$ & $\begin{array}{c}\text { Female Labor } \\
\text { Only (\%) }\end{array}$ \\
\hline Activities associated with tree planting & & & & \\
\hline Planting trees & 1233 & 40 & 26 & 34 \\
Adding manure & 1064 & 34 & 26 & 40 \\
Watering & 1207 & 28 & 30 & 33 \\
Fencing & 668 & 50 & 16 & 44 \\
Mulching & 642 & 33 & 22 & 32 \\
Pruning & 613 & 52 & 16 & \\
\hline
\end{tabular}

* Differences in number of observations is due to "other" having been selected for those involved or households not being involved in certain activities

We also assessed if farmers were likely to invest in tree planting, which species they would consider for future planting among the surveyed households and how many seedlings they would plant. Results show that $74 \%$ of women respondents in female-headed households, $75 \%$ of women respondents in male-headed households, $77 \%$ of men respondents in female headed households and $75 \%$ of men respondents in male-headed households would consider planting additional trees in future. In terms of species consideration, Mangifera indica was the most considered species for future planting by $64 \%$ of all the surveyed households. Other species considered were Melia volkensii (24\%), Carica papaya (21\%), Senna siamea (20\%) and Azadirachta indica (16\%). Additional analysis revealed no major differences in the tree species desired for future planting between women and men respondents (Figure 4). We however found variation in the overall number of seedlings considered between female headed and male headed households. The maximum number of tree seedlings considered for future planting by respondents from male headed households (1000 seedlings) was twice that of respondents from female headed households (500 seedlings).

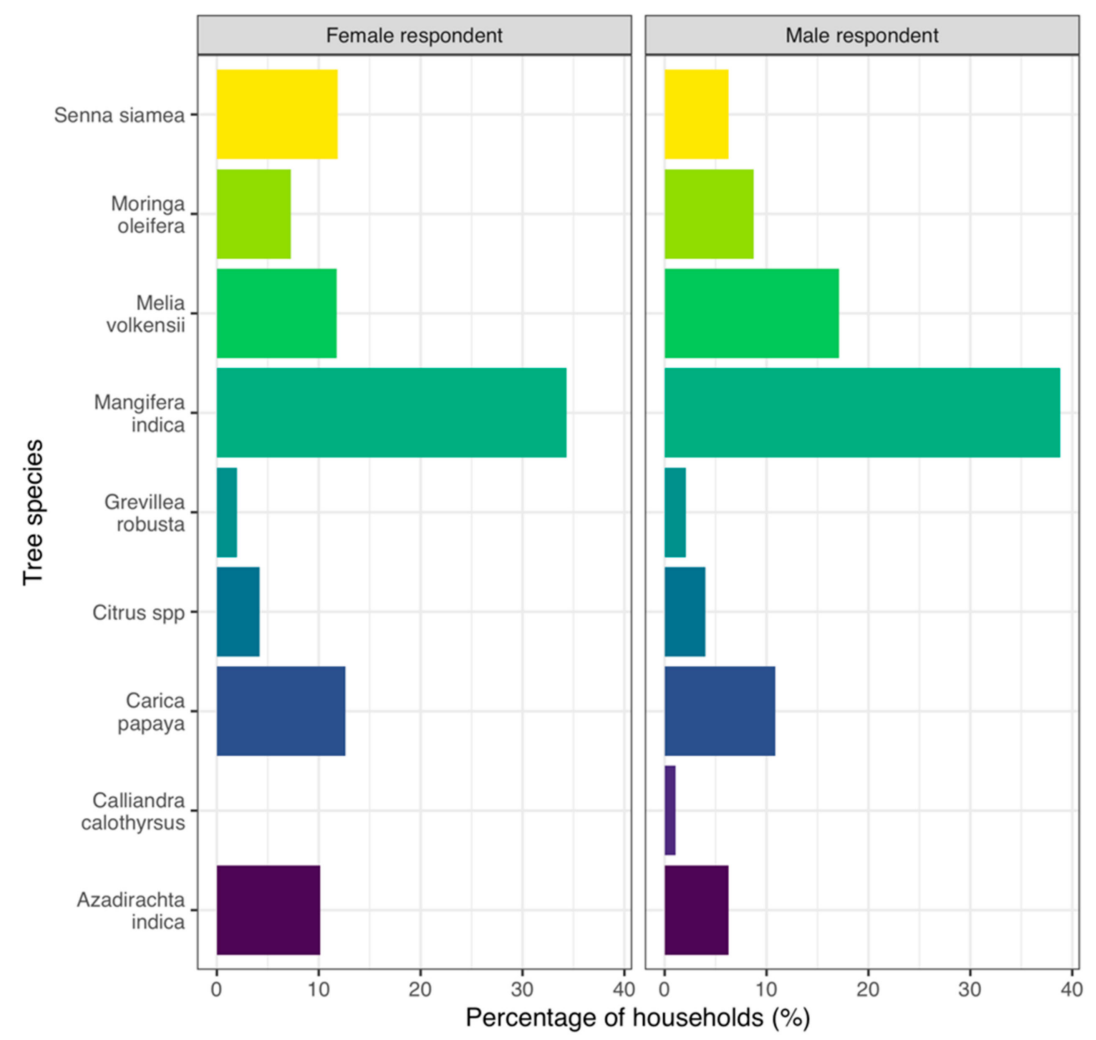

Figure 4. Species considered for future planting in female headed and male headed households by more than one percent of the surveyed households ( $n=644$ female respondents and 325 male respondents). 


\section{Discussion}

The survival rate of tree seedlings in drylands is characteristically low partly due to unreliable rainfall, high levels of land degradation resulting in low soil productivity, planting of ecologically unsuitable tree species, and poor tree seedling management practices [18-20]. While planting and management practices employed can have a positive or negative effect on tree survival, the use of these practices is usually determined by knowledge, needs, perceptions and, availability and access to resources the communities implementing them [41]. The results show that planting and management practices such as watering and watering regime, manure application and seedling protection by fencing had a significant effect on tree seedling survival.

However, the type of effect (whether positive or negative) as well as the magnitude of this effect varied depending on the sites in which they were employed. Variation in average tree survival was also observed across tree species under the planting and management practices. For example, Mangifera indica recorded higher average survival when planted in a big hole in all the study sites in Kenya while Melia volkensii recorded higher survival when planted with smaller hole size $(30 \mathrm{~cm}$ diameter by $45 \mathrm{~cm}$ depth). Water availability is a limiting factor to seedling survival especially in arid and semi-arid areas and the size of the planting hole can influence the water holding capacity. Bigger planting holes retain more water compared to smaller planting holes [35]. However, tree species have differing watering and management requirements. Additional discussion with farmers revealed that tree species such as Melia volkensii which are indigenous to arid and semi-arid areas are sensitive to waterlogging especially when young [42] and perform better when planted in smaller planting holes, while fruit trees such as Mangifera indica have a higher water requirement and perform better when planted in bigger planting holes.

That average seedling survival was higher when seedlings were physically protected from livestock across all the study sites in Kenya and Ethiopia was expected as browsing by livestock was reported as a key cause of seedling mortality across the study area. It is also consistent with findings by $[43,44]$ who in their studies, found seedling survival rate was higher in the fenced plots compared to those not fenced. Farmers across the study sites used makeshift fences made up of twigs, old mosquito nets and old clothes. In some cases, seedlings whose tip had been previously browsed off, regenerated. The observed differences in the significance of seedling protection between Kenya and Ethiopia can partly be attributed to the varying grazing practices across the two countries. In Ethiopia, farmers practice communal grazing with designated grazing areas and as such is easier to protect seedlings planted. In contrast, grazing in Kenya is at the discretion of individual farmers with many letting their livestock roam in the homestead especially during the dry season when access to fodder is limited. This is not to mean that browsing by livestock is not a threat to seedling survival in Ethiopia. In fact, Ref. [45] found that browsing by livestock deterred farmers in Ethiopia from adopting high-value agroforestry.

Furthermore, seedling source plays a key role in the viability of planting material and is often overlooked in tree planting campaigns [28]. This is because seedling stage is considered the most sensitive stage in the lifecycle of trees and seedling care from early establishment is critical to survival $[35,46]$. Tree seedlings distributed to farmers were sourced from different nurseries across the study sites due to the large number of seedlings required and the structure of nursery enterprises in the area, that is, most nurseries are smallholder owned and run. As a result, the quality of seedlings varied depending on the nursery from which the seedlings were sourced.

Results also revealed a relationship between the household's socioeconomic characteristics and the survival of the planted seedlings in both Kenya and Ethiopia. The strength of that relationship was however either weak or very weak suggesting while farmer circumstances can influence the odds of survival of planted seedlings, they are not, on their own, determining factors for seedling survival. Instead, they interact with other factors for example the agroecological conditions prevalent in the locality. They also enhance or limit access to resources such as knowledge, manure and water, which were found to significantly increase the chances of survival for seedlings. Our study also 
found variation in the effect of both biophysical characteristics of the farm such as erosion status and soil quality and socioeconomic characteristic of the household at both national and local scale. For example, seedlings had a higher likelihood of survival when farmers described the soil quality as high across most of the study areas in the two countries. This was expected as high soil quality means that the soil has the requisite nutrients to support plant growth. However, in Kitui Rural within Kitui County, seedlings had a higher likelihood of survival when farmers described their soil quality as low. This suggests that farmers who considered their soil quality low were perhaps investing more in use of external inputs such as manure to improve their overall soil quality compared to farmers who considered the quality of their soil as high. This thus calls for quantitative analyses on seedling survival to be combined with in-depth qualitative work to understand the reason behind the variation across study sites.

Our results also revealed variation in survival among farmers within the same locality and farmer circumstances implying that some farmers have better experience growing and managing trees compared to their neighbors [22]. This can perhaps be explained by inherent local knowledge that has shaped how they grow and manage their trees necessitating the need for complementarity between scientific knowledge and local knowledge if good practices around tree growing that are suited to local agroecological conditions and farmer circumstance are to be identified and shared [22].

Our findings on the role of men and women in tree planting and management activities show that men-only labor was predominantly used for management activities such as pruning and fencing while women-only labor was mostly used for watering, adding manure and adding mulch. This was consistent with findings from [47], who found that traditionally women were discouraged from taking part in activities such as fencing and pruning as they were considered strenuous. The results were also consistent with previous studies that found that where both men and women were involved in tree management, women tended to be involved in the initial stages of tree establishment [13,39]. This suggests that existing customs and traditions influence the role that both men and women play in managing natural resources and as such tree planting.

We also found very little difference in tree species preferred for future planting between respondents from female-headed households and those from male-headed households in Kenya. However, there was variation in the total number of seedlings to be planted with respondents from male-headed households willing to plant twice the number of seedlings planted by respondents from female-headed households. This could partly be explained by differences in access to capital needed to purchase seedlings, labor availability and farm size between male-headed and female-headed households. These results are also consistent with the study by [48] who found that female-headed households tended to plant half the number of trees and/or shrubs planted by male-headed households and attributed the difference to variation in farm size. Tree species that are commonly found in households across the study sites were mostly preferred. Furthermore, species compared by farmers in the study were the top preferred species for future planting among the surveyed households. This suggests that farmers prioritize tree species whose survival they can assure based on their local knowledge and past experience with the tree species, species whose availability they are sure of, the value they attach to the tree species and species for which there is an already established market or demand [22].

\section{Conclusions}

Tree planting can have a positive effect on the environment as well as on the social-economic realities of farmers if seedlings are managed ensuring survival to maturity. However, to scale successful tree planting efforts, context-specific variables should be considered as they can impact the survival of planting seedlings either positively or negatively. Our study found that planting seedlings with manure, watering them and protecting them from physical harm significantly increased the probability of survival in Kenya while in Ethiopia, watering, the planting niche and protection from harm significantly increased the probability of survival. Our findings show that tree planting and management practices such as application of manure, mulch and fencing can significantly increase survival indicating the 
need to not only invest in such practices but also in continuous engagement and training with farmers and local community on how to implement the practices on their farms.

We also show that socioeconomic characteristics of the household as well as the biophysical characteristics of the farm can enhance or hinder tree seedling survival. That variation in both the type and magnitude of effect on seedling survival was recorded in most of the assessed socioeconomic variables across the study sites indicates the need to understand and be cognizant of the local agroecological conditions and the farmer circumstances in which these practices are employed. Results also show the need to consider the different role men and women play in tree planting including in the management and use of the planted trees as this can have an influence on practices that are feasible for different farmers. Finally, we show the need to consider the priorities and interests of farmers as well as the inherent local knowledge especially when it comes to the species preferred as well as the need for training on additional beneficial species for planting.

Author Contributions: Conceptualization of the work by F.S., L.A.W.; methodology by P.S., J.M., L.A.W., C.M., N.H., K.H., F.S.; formal analysis conducted by C.M., L.A.W., A.F., H.O., N.H., I.O., M.C.; data curation by A.F., H.O., E.B., E.K., C.M.; writing—original draft preparation, C.M., L.A.W., M.C., A.F., H.O., N.H., P.S., I.O., E.K., A.K., J.M., S.C., K.H., E.B., F.S., visualization, C.M., L.A.W., A.F., H.O., I.O.; supervision by L.A.W., F.S.; funding acquisition By F.S. All authors have read and agreed to the published version of the manuscript.

Funding: This work was funded by International Fund for Agricultural Development (IFAD) and the European Commission through the project on Restoration of degraded lands for food security and poverty reduction in East Africa and the Sahel: taking successes to scale, grant numbers: 2000000520 and 2000000976 and the CGIAR Research Programme on Forests, Trees and Agroforestry (FTA). The work also received funding support from the European Commission and IFAD through the project on Kenya Cereal Enhancement Programme-Climate Resilient Agricultural Livelihoods (KCEP-CRAL) window.

Acknowledgments: The authors acknowledge the collaboration of the Drylands Development Programme funded by the Ministry of Foreign Affairs (MoFA) of the Netherlands and its implementing partners in Kenya and Ethiopia, including World Vision Kenya, Netherlands Development Organization (SNV), Caritas-Kenya, Adventist Development and Relief Agency Kenya (ADRA), World Vision Ethiopia (WVE), Relief Society of Tigray (REST), Ethiopian Orthodox Church's Development and Inter-Church Aid Committee (EOC-DICAC). This project was also supported in part by the CGIAR Research Programme on Forests, Trees and Agroforestry (FTA), We would like to acknowledge the support of the enumerators and community facilitators including Angellinah Kimanzi, Caroline Mbuvi, Francisca Mutua, Felix Mbuvi, Mercy Mwea, Silas Muthuri, Stephen Maithya, and Sylvester Muendo.

Conflicts of Interest: The authors declare no conflict of interest and that the funders had no role in the design of the study; in the collection, analyses, or interpretation of data; in the writing of the manuscript, or in the decision to publish the results.

\section{References}

1. Ministry of Environment and Forestry. National Strategy for Achieving and Maintaining over 10\% Tree Cover by 2022; Ministry of Environment and Forestry: Nairobi, Kenya, 2019.

2. Reubens, B.; Moeremans, C.; Poesen, J.; Nyssen, J.; TewoldeBerhan, S.; Franzel, S.; Deckers, J.; Orwa, C.; Muys, B. Tree species selection for land rehabilitation in Ethiopia: From fragmented knowledge to an integrated multi-criteria decision approach. Agrofor. Syst. 2011, 303-330. [CrossRef]

3. Coe, R.; Sinclair, F.; Barrios, E. Scaling up agroforestry requires research "in" rather than "for" development. Curr. Opin. Environ. Sustain. 2014, 6, 73-77. [CrossRef]

4. Sinclair, F.; Coe, R. The Options by Context Approach: A Paradigm shift in agronomy. Exp. Agric. 2019, 55, 1-13. [CrossRef]

5. Sinclair, F. System science at the scale of impact. In Sustainable Intensification in Smallholder Agriculture: An Integrated Systems Research Approach; Öborn, I., Vanlauwe, B., Phillips, M., Thomas, R., Brooijmans, W., Atta-krah, K., Eds.; Routledge: Abingdon, UK, 2017; pp. 43-57.

6. Kuria, A.; Pagella, T.; Winowiecki, L.A.; Mitiku, H.; Sinclair, F.L. Local knowledge promotes design of adaptive land restoration options that deliver multiple ecosystem services at scale. 2019. Manuscript in Preparation.

7. Ojiem, J.O.; de Ridder, N.; Vanlauwe, B.; Giller, K.E. Socio-ecological niche: A conceptual framework for integration of legumes in smallholder farming systems. Int. J. Agric. Sustain. 2006, 4, 79-93. [CrossRef]

8. Kindt, R.; Van Damme, P.; Simons, A.J. Tree Diversity in Western Kenya: Using Profiles to Characterise Richness and Evenness. Biodivers. Conserv. 2006, 15, 1253-1270. [CrossRef] 
9. Kindt, R.; Simons, A.J.; Van Damme, P. Do Farm Characteristics Explain Differences in Tree Species Diversity among Western Kenyan Farms? Agrofor. Syst. 2004, 63, 63-74. [CrossRef]

10. Crossland, M.; Winowiecki, L.A.; Pagella, T.; Hadgu, K.; Sinclair, F. Implications of variation in local perception of degradation and restoration processes for implementing land degradation neutrality. Environ. Dev. 2018, 28, 42-54. [CrossRef]

11. Coe, R.; Njoloma, J.; Sinclair, F. Loading the dice in favour of the farmer: Reducing the risk of adopting agronomic innovations. Exp. Agric. 2016, 55, 67-83. [CrossRef]

12. Kiptot, E.; Franzel, S. Gender and agroforestry in Africa: A review of women's participation. Agrofor. Syst. 2011, 84, 35-58. [CrossRef]

13. Naz, F.; Catacutan, D. Gender roles, decision-making and challenges to agroforestry adoption in Northwest Vietnam. Int. For. 2015, 22-32. [CrossRef]

14. Pehou, C.; Djoudi, H.; Vinceti, B.; Elias, M. Intersecting and dynamic gender rights to néré, a food tree species in Burkina Faso. J. Rural Stud. 2020, 76, 230-239. [CrossRef]

15. Bastin, J.; Finegold, Y.; Garcia, C.; Mollicone, D. The global tree restoration potential. Science 2019, 365, 76-79. [CrossRef] [PubMed]

16. Lohbeck, M.; Albers, P.; Boels, L.E.; Bongers, F.; Morel, S.; Sinclair, F.; Takoutsing, B.; Vågen, T.G.; Winowiecki, L.A.; Smith-Dumont, E. Drivers of farmer-managed natural regeneration in the Sahel. Lessons for restoration. Sci. Rep. 2020, 10, 15038. [CrossRef]

17. Brancalion, P.H.; Niamir, A.; Broadbent, E.; Crouzeilles, R.; Barros, F.S.; Zambrano, A.M.; Baccini, A.; Aronson, J.; Goetz, S.; Reid, J.; et al. Global restoration opportunities in tropical rainforest landscapes. Sci. Adv. 2019, 5, 1-12. [CrossRef]

18. De Leeuw, J.; Njenga, M.; Wagner, B.; Liyama, M. Treesilience: An Assessment of the Resilience Provided by Trees in the Drylands of Eastern Africa; De Leeuw, J., Njenga, M., Wagner, B., Liyama, M., Eds.; World Agroforestry Centre: Nairobi, Kenya, 2014; ISBN 9789290593522.

19. Ndegwa, G.; Iiyama, M.; Anhuf, D.; Nehren, U.; Schlüter, S. Tree establishment and management on farms in the drylands: Evaluation of different systems adopted by small-scale farmers in Mutomo District, Kenya. Agrofor. Syst. 2017, 91, 1043-1055. [CrossRef]

20. Syano, N.M.; Wasonga, O.V.; Nyangito, M.; Kironchi, G.; Egeru, A. Ecological and Socio-Economic Evaluation of Dryland Agroforestry Systems in East Africa. 2016. Available online: http://repository.ruforum.org (accessed on 19 January 2020).

21. Kuyah, S.; Öborn, I.; Jonsson, M.; Dahlin, A.S.; Barrios, E.; Muthuri, C.; Malmer, A.; Nyaga, J.; Magaju, C.; Namirembe, S.; et al. Trees in agricultural landscapes enhance provision of ecosystem services in Sub-Saharan Africa. Int. J. Biodivers. Sci. Ecosyst. Serv. Manag. 2016, 12, 255-273. [CrossRef]

22. Derero, A.; Coe, R.; Muthuri, C.; Hadgu, K.M.; Sinclair, F. Farmer-led approaches to increasing tree diversity in fields and farmed landscapes in Ethiopia. Agrofor. Syst. 2020. [CrossRef]

23. Iiyama, M.; Mukuralinda, A.; Ndayambaje, J.; Musana, B.; Ndoli, A.; Mowo, J.; Garrity, D.; Ling, S.; Ruganzu, V. Tree-Based Ecosystem Approaches (TBEAs) as multi-functional land management strategies-evidence from Rwanda. Sustainability 2018, 10, 1360. [CrossRef]

24. Mganga, K.Z.; Nyariki, D.M.; Musimba, N.K.R.; Mwang'ombe, A.W. Indigenous Grasses for Rehabilitating Degraded African Drylands. In Agriculture and Ecosystem Resilience in Sub Saharan Africa. Climate Change Management; Bamutaze, Y., Kyamanywa, S., Singh, B., Nabanoga, G., Lal, R., Eds.; Springer: Cham, Switzerland, 2019. [CrossRef]

25. Coe, R.; Hughes, K.; Sola, P.; Sinclair, F. Planned Comparisons Demystified; ICRAF Working Paper No 263; Nairobi World Agroforestry Centre: Nairobi, Kenya, 2017. [CrossRef]

26. Hughes, K.; Oduol, J.; Coe, R.; Sinclair, F.; Peralta, A. Guidelines for Identifying and Designing Planned Comparisons; ICRAF: Nairobi, Kenya, 2016.

27. Franzel, S.; Sinja, J.; Simpson, B. Farmer-to-Farmer Extension in Kenya: The Perspectives of Organizations Using the Approach; ICRAF Working Paper No. 181; World Agroforestry Centre: Nairobi, Kenya, 2014. [CrossRef]

28. Duguma, L.; Minang, P.; Aynekulu, E.; Carsan, S.; Nzyoka, J.; Bah, A.; Jamnadass, R. From Tree Planting to Tree Growing: Rethinking Ecosystem Restoration Through Trees; ICRAF Working Paper No 304; World Agroforestry: Nairobi, Kenya, 2020. [CrossRef] 
29. Hadgu, K.M.; Kooistra, L.; Rossing, W.A.H.; van Bruggen, A.H.C. Assessing the effect of Faidherbia albida based land use systems on barley yield at field and regional scale in the highlands of Tigray, Northern Ethiopia. Food Secur. 2009, 1, 337-350. [CrossRef]

30. Lemma, B.; Kleja, D.B.; Olsson, M.; Nilsson, I. Factors controlling soil organic carbon sequestration under exotic tree plantations: A case study using the CO2Fix model in southwestern Ethiopia. For. Ecol. Manag. 2007, 252, 124-131. [CrossRef]

31. County Government of Kitui. Kitui County Intergrated Plan 2018-2022; County Government of Kitui: Kitui, Kenya, 2018. Available online: https://www.cog.go.ke/downloads/category/106-county-integrateddevelopment-plans-2018-2022\# (accessed on 22 April 2020).

32. County Government of Machakos. Machakos County Intergrated Development Plan II (2018-2022). 2018. Available online: https://www.cog.go.ke/downloads/category/106-county-integrated-development-plans2018-2022\# (accessed on 22 April 2020).

33. County Government of Makueni. Makueni County Integrated Development Plan (Cidp) 2018-2022. 2018. Available online: https://www.cog.go.ke/downloads/category/106-county-integrated-development-plans2018-2022\# (accessed on 14 June 2019).

34. Sola, P.; Zerfu, E.; Coe, R.; Hughes, K. Community Visioning and Action Planning: Guidelines for Integrating the Options by Context Approach; ICRAF: Nairobi, Kenya, 2017.

35. Mwamburi, A.; Musyoki, J. Improving Tree Survival in the Drylands of Kenya: A Guide for Farmers and Tree Growers in the Drylands; Kenya Forestry Research Institute: Nairobi, Kenya, 2010.

36. R Core Team. R: A Language and Environment for Statistical Computing. Vienna, Austria, 2020. Available online: https://www.r-project.org (accessed on 8 January 2020).

37. Hagazi, N.; Hadgu, K.; Sitotaw, A.; Tofu, A.; Lavoll, V.; Winowiecki, L.; Magaju, C.; Nyaga, J.; Carsan, S.; Muriuki, J.; et al. Tree Planting Data 2017-Ethiopia 2019. MELDATA, V1. 2019. Available online: ahttps://hdl.handle.net/20.500.11766.1/FK2/O9LOGI (accessed on 11 March 2020).

38. Magaju, C.; Winowiecki, L.; Nyaga, J.; Ochenje, I.; Makui, P.; Kiura, E.; Crossland, M.; Valencia, A.M.; Kuria, A.; Carsan, S.; et al. Tree Planting Data 2018-Kenya 2019. MELDATA, V1. 2019. Available online: https://hdl.handle.net/20.500.11766.1/FK2/BLHHPR (accessed on 19 March 2020).

39. Kiptot, E.; Franzel, S.; Degrande, A. Gender, agroforestry and food security in Africa. Curr. Opin. Environ. Sustain. 2014, 6. [CrossRef]

40. Meijer, S.S.; Catacutan, D.; Ajayi, O.C.; Sileshi, G.W.; Nieuwenhuis, M. The role of knowledge, attitudes and perceptions in the uptake of agricultural and agroforestry innovations among smallholder farmers in sub-Saharan Africa. Int. J. Agric. Sustain. 2015, 13, 40-54. [CrossRef]

41. Maluki, J.M.; Kimiti, J.M.; Nguluu, S.; Musyoki, J.K. Adoption levels of agroforestry tree types and practices by smallholders in the semi-arid areas of Kenya: A case of Makueni County. J. Agric. Ext. Rural Dev. 2016, 8, 187-196. [CrossRef]

42. Kenya Forest Service. A Guide to Growing Melia Volkensii in the Dryland Areas of Kenya; Kenya Forest Service: Nairobi, Kenya, 2018.

43. Wassie, A.; Sterck, F.J.; Teketay, D.; Bongers, F. Effects of livestock exclusion on tree regeneration in church forests of Ethiopia. For. Ecol. Manag. 2009, 257, 765-772. [CrossRef]

44. Love, B.; Bork, E.; Spaner, D. Tree seedling establishment in living fences: A low-cost agroforestry management practice for the tropics. Agrofor. Syst. 2009, 77, 1-8. [CrossRef]

45. Iiyama, M.; Derero, A.; Kelemu, K.; Muthuri, C.; Kinuthia, R.; Ayenkulu, E.; Kiptot, E.; Hadgu, K.; Mowo, J.; Sinclair, F.L. Understanding patterns of tree adoption on farms in semi-arid and sub-humid Ethiopia. Agrofor. Syst. 2017, 91, 271-293. [CrossRef]

46. Bhadouria, R.; Singh, R.; Srivastava, P.; Raghubanshi, A.S. Understanding the ecology of tree-seedling growth in dry tropical environment: A management perspective. Energy Ecol. Environ. 2016, 1, 296-309. [CrossRef]

47. Crossland, M.; Valencia, A.M.P.; Pagella, T.; Magaju, C.; Kiura, E.; Winoweicki, L.; Sinclair, F. Onto the Farm, into the Household: Intrahousehold Gender Relations Matter for Scaling Land Restoration Practices, 2020; Manuscript Submitted for Publication. 
48. Kiptot, E.; Franzel, S. Gender and agroforestry in Africa: Are women participating. ICRAF Occas. Pap. 2011. [CrossRef]

Publisher's Note: MDPI stays neutral with regard to jurisdictional claims in published maps and institutional affiliations.

(C) 2020 by the authors. Licensee MDPI, Basel, Switzerland. This article is an open access article distributed under the terms and conditions of the Creative Commons Attribution (CC BY) license (http://creativecommons.org/licenses/by/4.0/). 